\title{
The Effect of Combined Treatment of Chiropractic and Shoulder Flexibility Exercises on the Balance Ability of the Deformed Cervical Alignment Subjects
}

\author{
II Yong Park', Mi Yong Lee ${ }^{2}$, Jae Ho Khil ${ }^{3, *}$ \\ 1 Gyeongnam Sports Industry Promotion Support Center, Korea \\ ${ }^{2}$ Chosun University Doctor of Complementary and Alternative Medicine, Korea \\ ${ }^{3}$ Kyunghee University International Campus Department of Sports Medicine, Korea
}

Received: October 7, 2020

Accepted: January 28, 2021

Published online: January 31, 2021

Keywords:

Cervical Alignment

Chiropractic

Dynamic Balance Ability

Shoulder Flexibility Exercises

Static Balance
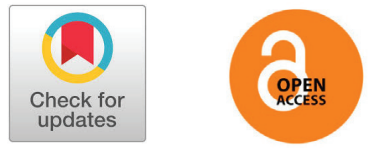

\section{ABSTRACT}

OBJECTIVES The purpose of this study is to analyze the effect of changes in cervical alignment on balance ability, to correct cervical alignment, and to present effective interventional variables that can improve balance ability.

METHODS Group 1 (Deformed cervical alignment group, $n=16$ ) and Group 2 (Normal cervical alignment group, $n=16$ ). The subjects measured their balance ability before and after treatment with chiropractic and shoulder flexibility exercises. Balance ability was measured by static balance and dynamic balance. For Group 1, chiropractic was treated once a week for 15 minutes, and shoulder flexibility exercise was treated three times a week for one hour. The pre- and post-measurement results of Group 1 were compared with Group 2, and differences among groups and groups were analyzed. The test method was tested with the Independent t-test and Paired t-test.

RESULTS Group 1 showed a significant reduction $(p<0.04)$ in the distance between the 7 th cervical spine and gravity line, showing an improvement in cervical alignment. In the static equilibrium, the significant difference that was measured beforehand disappeared and the sum of deflection decreased. The dynamic balance did not disappear significantly but the balance ability improved as the sum of deflection decreased. CONCLUSIONS The cervical alignment deformation affects the balance ability. A combination of cervical alignment correction and exercise to increase the flexibility of the shoulder and neck muscles were performed. As a result, it was a factor in improving the static balance and dynamic balance ability of the left and right sides of the cervical spine.

(c) The Asian Society of Kinesiology and the Korean Academy of Kinesiology
서론

현대인들의 일상에서 컴퓨터와 휴대전화 사용빈도 가 높아지고 있다. 우리나라에서 휴대전화 사용은 여성 (76.8\%)보다 남성(80.1\%)이 높으며, 연령별로는 20 대 가 $97.4 \%$ 로 가장 높게 나타났고 30 대, 10대, 40대 순으

*Correspondence: Jae Ho Khil, Sports Medicine, Kyunghee University, giheung-gu deog-yeongdaelo 1732, yong-insi, Republic Korea; Tel: +82-10-3938-7644; E-mail: jhkhil @khu.ac.kr
로 사용률이 높다고 조사되었다[1]. 현대인들이 영상단 말장비(visual display terminal, VDT)에 노출되는 시 간이 지속적으로 증가하고 있으며, 이러한 생활습관으 로 목과 어깨 이상을 호소하는 VDT증후군 환자 비율 또 한 증가하고 있다[2]. VDT증후군이란 $\mathrm{VDT}$ 를 오래 취 급하는 사람에게 발생하는 근골격계 질환, 정전기, 안정 피로 등에 의한 정신적 스트레스, 피부발진, 전자기파와 관련된 건강장애 등을 지칭하는 용어로 특히, 목벼질환 
의 원인이 된다[3-4]. 현대인의 직업적 특성과 생활환 경 속에서 불안정한 자세와 부적절한 작업환경에 노출 되는 빈도가 늘어나고 있으며 현대인의 근골격계 질환 발생 비율이 높아 졌음을 의미한다. 이러한 환경은 목뼈 질환 증가의 원인이 된다고 보고되었다[3].

부적합한 작업환경에 노출된 인체는 관절수용기 (Joint receptor)가 분포한 조직에 미세외상으로 인하 여 관절배열과 자세변화를 초래하며 목뼈정렬을 변화 시키는 원인이 될 수 있다. 서 있는 자세나 앉은 자세에 서 등뼈(Thoracic vertebra) 상부가 둥글게 굽게 되면 그 보상작용으로 목뼈의 위치도 변하게 된다[4]. 일상 생활의 잘못된 자세와 운동부족은 목뼈정렬변형을 초 래하며 특히, 목뼈 앞 굽음 감소를 초래하고 구조적으 로 머리 중심선을 앞쪽과 위쪽으로 이동시켜서 신전된 상부 목뼈가 내밈(Protraction)된 하부 목뼈와 함께 머 리를 앞으로 돌출시키게 된다[12]. 목뼈정렬의 앞 굽임 이 감소되는 변형은 양쪽 어깨 불균형(Asymmetrical) 이나 머리를 옆으로 기울게 하는 증상(Lateral tilt)도 유 발하는 근골격계 질환의 원인이 될 수 있다. 어깨와 목 뼈는 체중의 약 $1 / 7$ 에 해당하는 머리무게 압력을 직접 받기 때문에 목뼈 앞 굽음이 감소하면 중력의 수직방향 으로 평균보다 약 3.6 배 압력이 전달됨으로써 균형능력 에 영향을 미치게 된다[5]. 균형능력은 정적 균형과 동 적 균형으로 나누며, 정적 균형은 동작이 없는 상태에 서 중력중심을 지지기저면 내에 두고 자세를 유지하는 능력을 말하고, 동적 균형은 동작이 있는 상태에서 중 력 중심을 지지기저면 내에 두고 자세를 유지하는 능력 이다[6]. 현대인의 일상생활과 직업적 특성은 목뼈 변 형의 원인이 되며 균형능력에 영향을 미칠 수 있다. 여 기서 균형능력은 수의적 운동을 수행하며 자세 안정성 을 제공하기 때문에 일상생활과 보행에 영향을 미치는 중요한 역할을 한다[7].

변형된 목뼈정렬교정 방법으로 중요하지만 교정만 수행하거나 운동만을 처치하였을 때 변형된 목뼈정렬 을 고착화시키고 증상을 악화시킬 수 있다. 변형된 목뼈 정렬은 정상적인 목뼈정렬 보다 목뼈 앞 굽음이 감소하 고, 구조적으로 머리 중심선을 앞쪽과 위쪽으로 이동시 켜서 신전된 상부 목뼈가 내밈(Protraction)된 하부 목 뼈와 함께 머리가 전방으로 돌출시키기 때문이다[8]. 목 뼈 앞 굽음 감소는 양쪽 어깨의 불균형(Asymmetrical) 이나 머리를 옆으로 기울게 하는 증상(Lateral tilt)을 가
져오고 목뼈근육 불균형은 목뼈 뒤 굽음이 변형되는 증 상으로 이어진다. 이러한 목뼈정렬변형의 상관성을 분 석한 연구에서 목뼈 앞 굽음이 감소한 경우 앉은 자세와 바로선 자세에서 목뼈 신전이 유의하게 감소하였으며 목 뼈 통증과 신전의 상관성 또한 높다고 하였다[9]. 목뼈 정렬을 유지하고 운동기능을 지속하는 근육역할을 고려 한다면 변형된 목뼈 정렬을 교정하고 교정된 목뼈 정렬 을 유지하기 위한 운동을 복합 처치하는 것이 필요하다.

변형된 목뼈정렬교정 방법은 순간적인 밀기(Thrust) 를 포함하지 않는 수동적 관절운동으로 관절에 대한 도 수적 힘 적용을 의미하는 관절가동술이 있으며[10], 추 간판 돌출 감소와 후관절 기능부전 교정 및 잠긴 추체 관절 가동화, 신경근 압박감소, 반사활동 정상화, 근육 이완의 효과가 있다고 보고 되었다[11], 이와 같은 교 정법으로써 카이로프랙틱(Chiropractic)은 이상이 있는 척추분절에 교정을 가하는 것으로 척추 가동성을 증가 시키고 중추신경에서 내려진 명령을 말초신경의 원심성 신경체계를 거쳐 효과기관에 전달시키는데 효과적인 중 재방법으로 보고 되었다[12]. 카이로프랙틱 처치 효과 와 관련된 연구는 미국과 유럽을 중심으로 광범위하게 수행되었고 그 효과도 보고되고 있다[13].

$\mathrm{VDT}$ 증후군은 목과 어깨 부담을 가중하고 목뼈 안 정화를 위한 척추세움근(Cervical erector spine) 피로 를 유발한다[14]. 자세와 균형조절능력은 고위레벨의 신경회로나 인지적 요소, 근골격계 요소에 의해서도 영 향을 받는다[15]. 변형된 목뼈정렬은 관련 관절과 협 응력 등에 영향을 미치고, 균형능력과도 관련이 있지만 변형된 목뼈정렬과 균형능력 상관성에 대한 분석은 부 족하다. 다만, 목뼈와 카이로프랙틱 교정효과, 통증, 자 세변화, 메킨지프로그램 효과 등에 관한 선행연구는 다 수가 있다[16].

따라서 본 연구는 목뼈정렬변형이 정적 균형능력과 동적 균형능력에 미치는 영향을 분석하고, 변형된 목뼈 정렬을 교정하며 균형능력을 향상시키는데 효과적인 방 법으로 카이로프랙틱과 어깨와 목 근육 유연성을 높이 기 위한 운동프로그램을 복합 처치하여 효과적인 중재 방법을 제시하고자 한다. 


\section{연구방법}

\section{1. 연구대상}

본 연구는 연구계획에 대한 $\mathrm{K}$ 대학교 생명윤리심위 원회 승인(KHSIRB-17-042)을 받아서 진행하였다. 연구목적에 부합되는 참가자 수를 선정하기 위하여 $\mathrm{G}$-power 3.1.3 프로그램[17]을 이용하였다. 균형능 력과 목 장애지수, 목뼈정렬의 변화에 대한 변인을 측 정하기 위하여 Repeated measure, within-between interaction 방법으로 effect size $=.40, a=.05$, power= .80 을 설정하였으며 그룹 표본의 수는 16 명으로 요구 되었다. 참가자는 목 움직임이 불편하거나 통증을 느끼 는 20 30대 남녀로 제한하였으며 실험 참가 후 탈퇴 는 언제든지 자유의사에 의하여 가능하다는 것을 충분 히 설명하고 실험 참가 동의서(Approved participation agreement)를 받아서 본 연구를 진행하였다.

\section{2. 측정 항목 및 방법}

\section{1) 신체구성 및 체격}

신장 $(\mathrm{cm})$ 과 체중 $(\mathrm{kg})$ 은 간편한 복장으로 신발과 양 말을 벗고 장신구를 제거한 상태에서 다주파수 임피던 스기기(X-scan plus II, Jawon Medical, Korea)를 이 용하여 측정하였다. 신체질량지수(Body Mass Index: $\mathrm{BMI})$ 는 자동계산 된 측정 결과 (체중/신장 $2\left(\mathrm{~kg} / \mathrm{m}^{2}\right)$ )를 사 용하였다. 사전측정 후 8주 뒤에 사후 측정하였으며 총 2 회 측정하였다 〈Table 1$\rangle$.

Table 1. Physical characteristics of subjects (mean \pm SD)

\begin{tabular}{lccc}
\hline \multirow{2}{*}{ Variables } & \multicolumn{3}{c}{ Group } \\
\cline { 2 - 4 } & Group 1(n=16)* & Group 2(n=16)** & p \\
\hline Age (yrs) & $26.75 \pm 03.49$ & $26.38 \pm 04.24$ & 0.787 \\
Height (cm) & $169.32 \pm 07.85$ & $168.63 \pm 07.64$ & 0.803 \\
Weight (kg) & $69.52 \pm 15.66$ & $65.63 \pm 08.42$ & 0.389 \\
BMI $\left(\mathrm{kg} / \mathrm{m}^{2}\right)$ & $36.85 \pm 48.29$ & $2308 \pm 02.47$ & 0.263 \\
\hline
\end{tabular}

*Group 1: Cervical alignment, **Group 2: Normal cervical alignment

\section{2) 목뼈 굽음}

목뼈 굽음을 측정하기 위해서 X-ray(DXG-325R$\mathrm{RS}, \mathrm{MedWOW}$, Korea)를 촬영하였다. 피험자 안전 을 위하여 최소한의 X 선량을 이용하였다. 촬영방식은 C-spine AP로 거리 $10 \mathrm{~cm}, \mathrm{C}$-spine lateral 방식으로
는 거리 $180 \mathrm{~cm}$ 조건으로 촬영 장치 앞에 서서 목뼈 측 면 C1-C7을 촬영하였다.

목뼈정렬의 정확한 측정을 위해서 중력선 측정법 (Line of gravity)을 기준으로 목뼈변형 정도를 판단 하였다. 목뼈 앞 굽음 각 측정법(Cervical lordosis) 을 통하여 목뼈 1 번과 목뼈 2번을 측정하여 후-하방 으로 기울어졌을 경우는 정상적인 목뼈 앞 굽음으로 왜곡<Figure 1>될 수 있기 때문에 목뼈 각 깊이 측정 법(Depth of the cervical curve)으로 측정하였으며, Method of jochumse은 목뼈 1번 전면(Anterior arch) 과 목뼈 7번 척추 뼈 몸통(Body of vertebrae) 전상면 까지 직선을 연결한 선과 목뼈 5번 전방체까지 거리를 측정한 것으로 과전만(Hyperlordosis)은 $-9 \mathrm{~mm}$ 초과, 평균적 굽음은 $+3 \sim+8 \mathrm{~mm}$, 과소전만(Hypolordosis)은 $+1 \sim+2 \mathrm{~mm}$, 무전만(Cervical straight)은 $+1 \sim-3 \mathrm{~mm}$, 후만은 $-3 \mathrm{~mm}$ 미만을 보고하였다[18]. 목뼈의 X-ray 분석은 모두 외측(Lateral view) 사진상태에서 분석하 였으며 촬영할 때 대상자 자세는 전방 $15^{\circ}$ 시선높이로 고정하고 측면자세를 촬영하였다. 중력선 측정법은 목 뼈 2번의 치상돌기 상부중앙에서 지면과 수직되는 선을 그었을 때 이 수직선이 목뼈 7번의 중앙에 위치하는 것 을 기준(Gravity line, Front)으로 중앙에서 벗어날 경 우 목뼈변형으로 판단하였다.

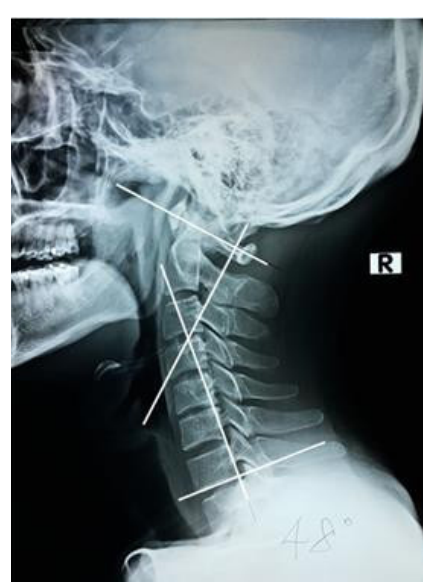

(A) Cervical lordosis

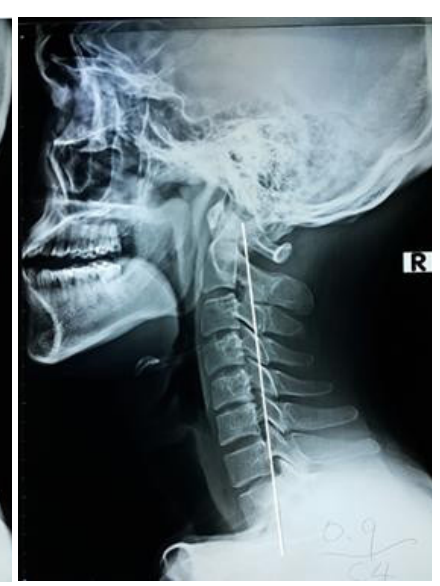

(B) Line of gravity
Figure 1. Distortion phenomenon of cervical lordosis measurement method due to posterior downward displacement of cervical vertebrae 1 and 2

\section{3) 정적 균형능력}

균형능력(Static \& Dynamic balance)의 측정은 Posturomed(Hyder, Germany)로 측정하였으며 측정 
방법은 측정 전 피험자에게 측정자세를 설명하고, 학습 효과(Test-retest effect)를 최소화 하기 위하여 좌측 측정 후, 1 분 동안 휴식하고 사전연습 없이 측정하였다. 우측도 좌측과 같은 방법으로 측정하였다. 균형능력측 정은 신경-정형 치료에 응용되며 균형 측정을 위해 설 치된 2개의 작은 초음파 마커(Ultrasonic marker)에서 나오는 X축과 $\mathrm{Y}$ 축으로 흔들리는 신호를 $3 \mathrm{D}$ 동작 분석 기인 CMS 10 Measuring System(Zebris, Germany) 로 움직이는 거리에 대한 Interface를 통하여 DigiMax Posturomed (Version1.2) 로 측정하였다.

정적 균형은 좌측과 우측을 각각 1 회 측정하였다. 좌 측다리 정적 균형은 우측 다리를 왼쪽 무릎 높이까지 들 어 올리고 무릎관절을 구부려 $90^{\circ}$ 유지하여 20초 동안 편향성을 측정하였다. 이 때 참가자가 균형을 잃으면 손 으로 측정기에 설치된 좌우 바(Bar)에 대한 가벼운 접 촉은 허용하였다.

\section{4) 동적 균형능력}

동적 균형은 좌측과 우측을 각각 1 회 측정하였다. 균 형능력측정기 앞에 매트를 깔고 $20 \mathrm{~cm}$ 장애물을 설치하 여 장애물과 접촉되지 않는 상태에서 두 발로 뛰게 하였 다. 측정하는 다리의 한 발로 착지 후 20초 동안 편향성 을 측정하였다. 피험자 균형을 잃게 되면 측정기 양쪽 에 설치된 바(Bar)를 손으로 가벼운 접촉은 허용하였지 만 잡거나 양쪽 발이 바닥에 닿으면 측정실패로 판단하 고 다시 측정하였다.

\section{3. 처치프로그램}

\section{1) 카이로프랙틱}

카이로프랙틱 처치는 시술자 주로 사용하는 손으 로 접촉한 허리뼈 가로돌기에 접촉하게 하여 낮은 진 폭과 시계 또는 반 시계 방향으로 빠르고, 세게(Low amplitude, high velosity) 회전시키며 미는(Thrust) 간스테드교정법(Gonstead technique)을 실시하였다 [19]. 카이로프랙틱을 처치하는 동안, 근육수축으로 인 한 인대 손상을 예방하기 위하여 근막이완법을 10 분 동 안 처치하고 카이로프랙틱을 주 1회, 5 분 동안 비침습 적(Noninvasive) 방법으로 척추와 골반을 중심으로 관 절변위 균형을 회복시킬 수 있도록 8주 동안 근막이완 법 80분, 카이로프랙틱 40분 시행하였다. 카이로프랙틱 처치 후에 척추 안정성을 유지하며 어깨 가동범위를 증
가시킬 수 있도록 어깨 안정화 운동을 복합 처치하였다. 피험자에게는 다른 변수가 될 수 있는 운동프로그램 및 수기요법 참여를 제한하였다.

\section{2) 어깨 유연성 강화 운동}

어깨의 유연성 증가를 위한 운동(Shoulder Flexibility Exercise)은 8주 동안 주3회 Warm-up 15 분을 진행하였고, Main exercise를 A(Starting position), B(Shoulder external rotation), C(Shoulder internal rotation), D(Shoulder internal rotation with 90 degree abduction), E(Shoulder flexion with internal rotation), F(Finish position: shoulder abduction) 순서로 각각 10회씩 순차적으로 반복하는 것을 1 세트로 하여, 총 3 세트를 피험자가 실시하도록 하였다. 운동시간은 1 회당 30 분, Cool down은 15 분으 로 진행하였다<Table 2>. 운동 빈도(Frequency)는 8 주 동안 주 3 회, 총 24 회 실시하였다. 어깨의 유연성 증가를 위한 처치에 대한 강도(intensity)는 운동 자각 도(Rate of Perceived Exertion: RPE)를 활용하였고, 1-4주 동안에는 운동 자각도(RPE)가 13 14에 해당하 는 약간 힘든 정도가 되도록 하였고, 4-8주까지는 RPE 15 17, 4주부터는 RPE 15 17로 유지하였다. 운동프 로그램은 $\mathrm{K}$ 대학 체육 교육실에서 피험자들과 함께 프 로그램(Group exercise)을 진행하였다.

\section{3. 자료처리 방법}

본 연구에서 얻어진 모든 결과는 SPSS PC+ for Windows(version 26.0) 통계 프로그램을 이용하여 분 석하였다. 두 그룹의 신체적 특성과, 편향성 변화를 분석 하기 위하여 기술통계값을 제시하고 평균(Mean)과 표준 편차(Standard Deviation: SD)를 산출하였다. ShapiroWilk검정으로 정규성을 검정하였으며 정규성이 성립하 여 실험군(Group 1)과 대조군(Group 2)의 모수통계방 법으로 검정하였다. 그룹간의 평균 차이에 검정을 위해 독립표본 $\mathrm{t}$-검증과 그룹 내 평균 차이의 검정을 위해서 대응표본 $\mathrm{t}$-검증을 실시하였다. 모든 분석의 통계적 유 의수준 $(a)$ 은 0.05 로 설정하였다 
Table 2. Flexibility exercise program

\begin{tabular}{|c|c|c|c|c|c|}
\hline Order & Time & Period (week) & Type & Intensity & Frequency \\
\hline & & & Dynamic Stretching & & \multirow{4}{*}{$\begin{array}{l}3 \text { days } \\
\text { /week }\end{array}$} \\
\hline $\begin{array}{l}\text { Warm } \\
\text {-up }\end{array}$ & $\begin{array}{c}15 \\
\min \end{array}$ & $1-8$ & $\begin{array}{l}\text { - Standing Plantar Flexor } \\
\text { - Standing Toe Extensor and Flexor } \\
\text { - Standing Knee } \\
\text { - HIP External and Internal Rotator } \\
\text { - Hip Adductor and Abductor } \\
\text { - Hip Flexor and Extensor } \\
\text { - Trunk Lateral Flexion and Trunk Rotator } \\
\text { - Shoulder Extensor and Adductor and Retractor } \\
\text { - Neck Extensor and Rotation }\end{array}$ & & \\
\hline $\begin{array}{l}\text { Main } \\
\text { Exercise }\end{array}$ & $\begin{array}{c}30 \\
\min \end{array}$ & $\begin{array}{c}1-4 \\
(3 s e t) \\
5-8 \\
\text { (3set) }\end{array}$ & $\begin{array}{l}\text { - A. Starting position } \\
\text { - B. Shoulder External Rotation } \\
\text { - C. Shoulder Internal Rotation } \\
\text { - D. Shoulder Internal Rotation with 90degree Abduction } \\
\text { - E. Shoulder Flexion with Internal Rotation } \\
\text { - F. Finish Position: Shoulder Abduction }\end{array}$ & $\begin{array}{l}\text { RPE : } \\
13-14 \\
\text { RPE : } \\
15-17\end{array}$ & \\
\hline $\begin{array}{l}\text { Cool } \\
\text {-down }\end{array}$ & $\begin{array}{c}15 \\
\min \end{array}$ & $1-8$ & $\begin{array}{l}\text { Static Stretching } \\
\text { - Seated Knee Flexor } \\
\text { - Seated Knee, Ankle, Shoulder, and Back } \\
\text { - Seated Hip Adductor } \\
\text { - Recumbent Hip External Rotator and Extensor } \\
\text { - Intermediate Lying Knee Extensor }\end{array}$ & & \\
\hline
\end{tabular}

\section{결과}

\section{1. 목뼈정렬 변화}

사전 측정 후 8 주 동안 목벼정렬을 변화시키기 위한 카이로프랙틱과 정렬된 목뼈를 안정적으로 유지할 수 있 는 어깨 유연성 강화운동을 복합적으로 처치한 결과 변 형된 목뼈정렬을 평가하기 위하여 목뼈 2번 치상돌기 상 부 중앙에서 지면과 수직되는 선을 그었을 때 이 수직선 이 목뼈 7 번 몸통을 지나가는지를 판단하였던 Gravity line, Front에서 유의한 감소 $(\mathrm{p}<0.04)$ 가 나타나면서 목 뼈정렬이 변화되었다<Table 3 >

Table 3. Changes in cervical alignment (mean \pm SD)

\begin{tabular}{llccc}
\hline \multirow{2}{*}{ Group 1(n=16) } & & \multicolumn{3}{c}{ Paired t-test } \\
\cline { 3 - 5 } & & mean \pm SD & t & P \\
\hline \multirow{2}{*}{ Gravity line $(\mathrm{mm})$} & Front & $0.22 \pm 0.39$ & 2.23 & $0.04^{*}$ \\
& Center & $0.34 \pm 0.64$ & 2.12 & 0.05 \\
Lordosis angle $\left({ }^{\circ}\right)$ & & $1.25 \pm 7.05$ & 0.71 & 0.49 \\
Depth $(\mathrm{mm})$ & Distance & $0.09 \pm 0.29$ & 1.28 & 0.22 \\
\hline
\end{tabular}

${ }^{*} p<.05$ : There is a statistically significant difference between pre- and post-test.

\section{2. 균형능력 변화}

\section{1) 정적 균형능력}

Group 1과 Group 2에서 사전 측정된 정적 균형능 력은 좌측 $\mathrm{Y}$ 축 편향성에서 유의한 차이 $(\mathrm{p}<0.03)$ 가 나 타났다. 정적 균형능력에서 목벼정렬 차이는 좌측 전후 편향성에서 균형능력 차이가 나타난 것으로 판단할 수 있다. 좌측 $\mathrm{X}$ 축과 우측 $\mathrm{X}, \mathrm{Y}$ 축에서는 Group 1 과 Group 2 에서 편향성이 높게 나타났다 〈Table 4>. 이러한 결 과는 사전 측정된 정적 균형능력에서 Group 1은 Sum of deflection Lx, Ls, Rx, Rs에서 Group 2보다 높은 편향성이 나타났다. 사전 측정된 편향성은 좌우 수평적 인 차이가 나타났지만 유의한 차이가 없었던 반면 사후 측정된 정적 상태에서 균형능력은 좌측다리 $\mathrm{X}$ 축인 $\mathrm{Lx}$ $\ulcorner \%(-83.24)$, 좌측다리 $\mathrm{Y}$ 축인 $\mathrm{Ly}\ulcorner \%(-80.83)$, 좌측다 리 편향성 합에서 Ls $\Gamma \%(-82.24)$ 의 편향성이 감소하 였다 $(\mathrm{p}<0.00)$. 한편, 정적 상태에서 우측다리 $\mathrm{X}$ 축 편향 성 $\mathrm{Rx}\lceil \%(-84.86)$, 오른쪽 다리 $\mathrm{Y}$ 축 Ry $\% \%(-81.00)$, 오른쪽 다리 편향성 합은 Rs $\Gamma \%(-83.73)$ 감소함으로 써 정적인 상태에서 좌측과 우측다리 모두 편향성이 유 의 $(\mathrm{p}<0.00)$ 하게 감소하였다 〈Table $5>$. 


\section{2) 동적 균형능력}

Group 1과 Group 2에서 사전 측정된 동적 균형

형능력은 좌측다리 X축 $\mathrm{Lx} 「 \%(-64.47)$, 좌측다리 Y 능력은 Sum of deffection $\operatorname{Lx}(\mathrm{p}<0.00), \operatorname{Ly}(\mathrm{p}<0.01)$, $\mathrm{Ls}_{\mathrm{s}}(\mathrm{p}<0.00)$, Sum of deflection $\operatorname{Rx}(\mathrm{p}<0.00)$, 축 Ly $\%(-58.74)$, 좌측다리 편향성 합 Ls $\%$ 이 감소 $\mathrm{Ry}(\mathrm{p}<0.01), \mathrm{Rs}_{\mathrm{S}}$ 서 유의한 차이 $(\mathrm{p}<0.00)$ 가 나타났 다 <Table $4>$. 우측다리 X축과 $\mathrm{Y}$ 축에서 편향성에서 (-62.63)하였다. 한편, 동적 상태에서 오른쪽 다리 X 축 편향성 $\mathrm{Rx}\lceil \%(-64.54)$, 오른쪽 다리 Y축 Ry 「\%($57.32)$, 오른쪽 다리 편향성 합은 Rs 「\%(-61.20)로 유 유의한 차이 $(\mathrm{p}<0.00)$ 를 보였고, 사후 측정된 동적 균

Table 4. The difference between the means of two independent groups (mean $\pm S D$ )

\begin{tabular}{|c|c|c|c|c|c|c|c|c|c|}
\hline \multirow{3}{*}{ Group } & & \multicolumn{4}{|c|}{ Independent t -test } & \multirow{2}{*}{\multicolumn{2}{|c|}{ St* }} & \multirow{2}{*}{\multicolumn{2}{|c|}{ Dy** }} \\
\hline & & \multicolumn{2}{|c|}{$\mathbf{S t}^{*}$} & \multicolumn{2}{|c|}{ Dy** } & & & & \\
\hline & & pre(n=16) & $\operatorname{post}(n=16)$ & $\operatorname{pre}(n=16)$ & $\operatorname{post}(n=16)$ & $\mathrm{t}$ & $\mathrm{p}$ & $\mathrm{t}$ & $\mathrm{p}$ \\
\hline \multirow{2}{*}{ Lx } & 1 & $2240.28 \pm 1152.60$ & $375.37 \pm 217.60$ & $1512.41 \pm 723.91$ & $537.31 \pm 245.92$ & 0.97 & 0.34 & -3.34 & $0.00^{*}$ \\
\hline & 2 & $1753.09 \pm 1637.30$ & $1753.09 \pm 1637.30$ & $1479.26 \pm 1157.30$ & $1479.26 \pm 1157.30$ & & & & \\
\hline \multirow{2}{*}{ Ly } & 1 & $947.91 \pm 445.54$ & $181.69 \pm 91.47$ & $644.92 \pm 437.00$ & $266.06 \pm 149.97$ & 2.23 & $0.03^{*}$ & -2.76 & $0.01^{*}$ \\
\hline & 2 & $558.32 \pm 538.83$ & $558.32 \pm 538.83$ & $467.13 \pm 392.65$ & $467.13 \pm 392.65$ & & & & \\
\hline \multirow{2}{*}{ Ls } & 1 & $2579.34 \pm 1279.43$ & $458.09 \pm 236.85$ & $1757.01 \pm 893.61$ & $656.54 \pm 302.62$ & 1.16 & 0.26 & -3.28 & $0.00^{*}$ \\
\hline & 2 & $1942.29 \pm 1792.55$ & $1942.29 \pm 1792.55$ & $1625.98 \pm 1235.59$ & $1625.98 \pm 1235.59$ & & & & \\
\hline \multirow{2}{*}{$R x$} & 1 & $2139.56 \pm 1252.12$ & $323.91 \pm 182.36$ & $1317.16 \pm 891.63$ & $467.04 \pm 254.09$ & 0.82 & 0.42 & -3.59 & $0.00^{*}$ \\
\hline & 2 & $1727.81 \pm 1555.47$ & $1727.81 \pm 1555.47$ & $1124.40 \pm 965.26$ & $1124.40 \pm 965.26$ & & & & \\
\hline \multirow{2}{*}{ Ry } & 1 & $834.04 \pm 493.26$ & $158.46 \pm 96.68$ & $529.37 \pm 304.88$ & $225.94 \pm 129.41$ & 1.31 & 0.20 & -2.90 & $0.01^{*}$ \\
\hline & 2 & $585.23 \pm 579.72$ & $585.23 \pm 579.72$ & $387.03 \pm 298.56$ & $387.03 \pm 298.56$ & & & & \\
\hline \multirow{2}{*}{ Rs } & 1 & $2440.54 \pm 1379.88$ & $397.13 \pm 209.49$ & $1454.77 \pm 941.93$ & $564.46 \pm 295.58$ & 0.92 & 0.36 & -3.53 & $0.00^{*}$ \\
\hline & 2 & $1932.12 \pm 1726.88$ & $1932.12 \pm 1726.88$ & $1263.61 \pm 1046.42$ & $1263.61 \pm 1046.42$ & & & & \\
\hline \multicolumn{10}{|c|}{ 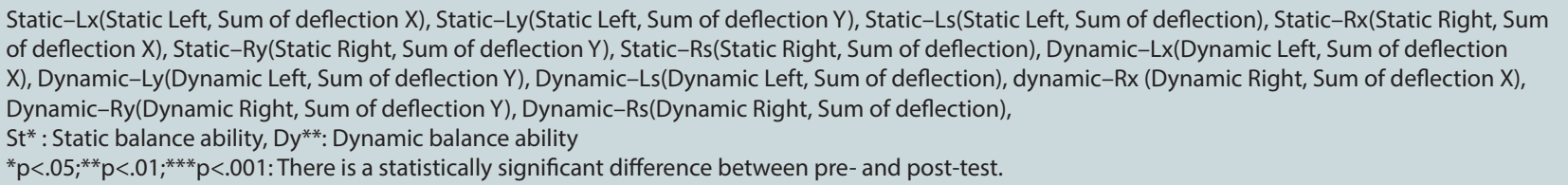 } \\
\hline
\end{tabular}

Table 5. Differences in pre-post-measured Static and Synamic balance ability

\begin{tabular}{|c|c|c|c|c|c|c|c|c|c|}
\hline \multirow{3}{*}{\multicolumn{2}{|c|}{$\begin{array}{l}\text { Group } \\
\text { post-pre }\end{array}$}} & \multicolumn{8}{|c|}{ Paired t -test } \\
\hline & & \multirow{2}{*}{ St* } & \multirow{2}{*}{ Dy** } & \multicolumn{2}{|c|}{$\Delta \%$} & \multicolumn{2}{|c|}{$\mathbf{S t}^{*}$} & \multicolumn{2}{|c|}{ Dy** } \\
\hline & & & & St* & $D y^{* *}$ & $\mathbf{t}$ & $\mathbf{p}$ & $\mathbf{t}$ & $\mathbf{p}$ \\
\hline Lx & 1 & $932.45 \pm 1228.32$ & $487.55 \pm 714.41$ & -83.24 & -64.47 & 4.29 & $0.00^{*}$ & 3.86 & $0.00^{*}$ \\
\hline Ly & 1 & $383.11 \pm 483.83$ & $189.43 \pm 361.04$ & -80.83 & -58.74 & 4.48 & $0.00^{*}$ & 2.97 & $0.01 *$ \\
\hline Ls & 1 & $1060.63 \pm 1380.78$ & $550.23 \pm 844.02$ & -82.24 & -62.63 & 4.35 & $0.00^{*}$ & 3.69 & $0.00 *$ \\
\hline $\mathrm{Rx}$ & 1 & $907.83 \pm 1248.77$ & $425.06 \pm 740.72$ & -84.86 & -64.54 & 4.11 & $0.00^{*}$ & 3.25 & $0.00^{*}$ \\
\hline Ry & 1 & $337.79 \pm 471.51$ & $151.72 \pm 265.20$ & -81.00 & -57.32 & 4.05 & $0.00^{*}$ & 3.24 & $0.00 *$ \\
\hline Rs & 1 & $1021.70 \pm 1390.15$ & $445.16 \pm 777.21$ & -83.73 & -61.20 & 4.16 & $0.00^{*}$ & 3.24 & $0.00^{*}$ \\
\hline
\end{tabular}

$\mathrm{St}^{*}$ : Static balance ability, Dy**: Dynamic balance ability $\Delta \%=\left(\right.$ post-pre) $/$ pre ${ }^{*} 100,{ }^{*} p<.05 ;{ }^{* *} p<.01 ;{ }^{* * *} p<.001$ 


\section{논의}

본 연구는 목뼈정렬변형과 목 주변 근육이 균형능력 에 미치는 영향을 분석하고, 목뼈정렬과 목 주변 근육 유연성을 회복하기 위한 효과적인 교정법과 운동프로그 램을 제시하고자 하였다. 피험자 동의를 얻어서 X-ray 를 촬영하고 변형된 목뼈정렬을 확인하였다. 변형된 목 뼈정렬이 나타난 피험자를 대상으로 8주 동안 카이로 프랙틱 처치와 목과 어깨근육의 유연성을 강화하기 위 한 운동프로그램을 복합 처치하였다.

목뼈 앞 굽임이 감소한 자세와 목뼈 뒤 굽임이 형성 된 자세가 목 통증에 미치는 상관관계를 분석한 연구에 서 목뼈 앞 굽임이 감소한 경우 앉은 자세와 바로선 자 세에서 목뼈신전이 유의하게 감소하였으며, 목 통증과 신전의 상관성이 높다고 보고하였다[13]. 목빼정렬 변 형은 통증을 유발하며 자세변형을 초래하는 근골격질환 의 원인이 될 수 있는 것이다.

기계적 목뼈 장애 환자의 도수치료 효과에 대한 실험 연구논문 33개를 분석한 연구에 의하면 [20], 변형된 목 뼈를 교정하기 위한 방법으로 도수교정(Manipulation) 이나 관절가동술(Mobilization)의 단독적용은 효과적이 지 못하며 운동프로그램을 함께 적용한 경우에만 효과 가 있었다. 잘못된 자세가 반복됨으로써 형성된 목뼈나 척추변형이 운동이나 교정만으로 바로 잡을 수는 없다 는 것을 의미한다. 변형된 목뼈나 척추 불균형이 교정 되지 않은 상태에서 운동은 변형된 목뼈나 척추정렬을 고착화를 초래하며 증상을 악화시킬 수 있기 때문이다. 목뼈나 척추정렬변형은 근골격계와 신경계 및 감각 손 상 등 각종 질환을 유발하며 [21] 균형능력에 영향을 미 치기 때문에 목뼈변형과 균형능력에 대한 상관성을 구 체적으로 구분하여 연구할 필요성이 있다.

본 연구에서 어깨 근육 유연성을 증가시키기 위한 운 동과 카이로프랙틱을 복합 처치하였던 Group 1은 목뼈 정렬이 유의하게 변화되었다. 사전측정에서 정상적인 Group 2보다 높은 편향성을 보였던 균형능력 또한 그 편향성이 감소되었으며 Group 1 정적 균형능력과 동적 균형능력 모두 향상되었다. 척주 안정성과 몸통 안정화 와 함께 목 안정화 운동은 자세조절과 균형능력에 주요 한 영향을 미친다는 선행연구와도 매우 유사한 결과이 다[22]. 목뼈 및 등뼈(Thoracic vertebrae) 부위 스트 레칭과 근력 강화 운동프로그램이 목뼈 앞 굽음이 감소
된 자세에 미치는 효과를 분석한 선행연구 [23]는 자세 교육과 운동을 복합처치 하였을 때 Cranio vertebral angle(CVA)과 Cranial rotation angle: CRA)에서 유 의한 차이가 나타났으며 본 연구도 선행연구결과와 유 사한 결과를 보였지만 Group 1 사후측정에서 Gravity line의 Front와 Center에서 유의한 차이가 나타나면서 Gravity line이 Group 2와 가깝게 변하였다. 목뼈정렬 변형을 빠르게 발견할수록 자세교정에 보다 효과적이라 고 보고하였다[24]. 변형된 목뼈정렬을 빠른 시기에 교 정할 필요성을 의미한다. 목뼈정렬변형은 목뼈 앞 굽음 이 감소하고 뒤 굽음이 형성되기 때문이다. 잘못된 자 세로 인해 변형된 목뼈는 척주의 전반적인 자세에 영향 을 미치므로 척추 각 분절의 균형이나 근력균형을 위하 여 근육계의 통합된 운동시스템으로 척주 안정성과 적 절한 기능을 유지하는 것이 중요하다[17]. 그리고, 현 대인의 일상과 직업환경 및 인구구조의 변화를 고할 때 균형능력은 수의적 운동을 수행하며 자세 안정성을 제 공하기 때문에 일상생활에서 보행이나 낙상 위험 예방 을 위한 중요한 역할을 한다[7].

본 연구는 사전측정에서 Group 1의 정적 균형을 측 정한 편향성이 Group 2보다 높게 측정되었지만 사후측 정에서 편향성 좌측과 우측 $\mathrm{X}$ 축과 $\mathrm{Y}$ 축 모두 편향성이 감소하며 균형 능력이 향상되었다. 그리고 카이로프랙 틱 처치효과로 목뼈정렬이 변화되었으며 어깨 유연성 증가를 위한 운동으로 교정된 목뼈가 안정된 상태로 유 지되면서 균형능력이 향상된 것이라고 할 수 있다. 이 러한 결과는 목뼈 앞 굽음이 변화되어 자세조절에 영향 을 준 것과 관련이 있다[19]. 교정운동이 척추 뒤 굽음 이 변형된 환자의 척추 굽음과 평형성에 미치는 영향을 연구한 선행연구에서는 척추 뒤 굽음 환자들에게 교정 운동을 적용하였으며 Cobb's angle, 목뼈 위치각, 평형 감각 변인을 분석한 결과 교정운동이 척추 뒤 굽음 환자 의 균형능력과 보행 능력에 영향[20] 줄 수 있다는 연 구와도 매우 유사하다고 할 수 있다.

본 연구에서는 사전 측정된 정적 편향성에서 좌측 $\mathrm{Y}$ 축에서만 유의한 차이가 나타났다. 이러한 결과는 변형 된 목뼈정렬이 좌측다리로 지지된 상태의 균형능력에서 전후 편향성에 불안정한 요인으로 작용한 것으로 판단된 다. 사후 측정결과 $\%$ 만큼 편향성이 감소하였고 이것은 균형의 불안정한 요인으로 작용한 $\mathrm{Y}$ 축 편향성 감소 때문 이라고 생각된다. 선행연구도 선수의 균형능력이 낮을 
때 발목 부상의 위험도가 높아지고 균형능력은 특히, 발 목손상을 예측하는 중요 요인으로 작용하며 균형능력이 낮을수록 더 많은 발목손상이 나타났다[20]. 목뼈변형 만 균형능력에 영향을 주는 것은 아니지만 다른 요인과 함께 연구되어야 할 필요가 있다[24]. 균형능력은 스포 츠 손상을 예측하고 낙상예방에도 도움을 주며 그 효과 는 운동수행능력에 영향을 줄 것이기 때문이다. 목뼈 앞 굽음이 감소한 환자를 대상으로 카이로프랙틱과 $\mathrm{PNF}$ 운동을 복합 처치하였을 때 통증척도(VAS)와 자율신경 기능에 유의하게 개선된 결과가 보고되었다[22]. 일반 적으로 변형된 목뼈정렬에 대하여 맥캔지 프로그램과 함께 자세변화와 통증, 목뼈정렬변화를 향상시키기 위 한 운동은 근육강도와 관절가동범위를 증가시키며 통증 감소와 자세변화에도 도움이 된다고 보고 하였다[25].

앞 굽음이 변형된 목뼈정렬을 보이는 대상자에게 카 이로프랙틱과 맥캔지 프로그램을 함께 처치하고 목과 머 리의 불안정한 상태를 안정시키는데 긍정적 결과를 보 고한 선행연구 [26]와 같이 위등세모근, 깊은목굽힘근, 어깨올림근 신장과 마름근, 아래등세모근 운동을 통해 부분에서 상체 근육전체를 움직이는 본 연구와 같은 프 로그램이 처치되어야 할 것이다.

본 연구에서는 목뼈정렬변형을 세분화하지 않았지 만 목뼈 앞 굽음이 감소한 목뼈와 뒤 굽음이 형성된 목 뼈변형을 구분하여 연구할 필요가 있다. 왜냐하면 변형 된 정도가 목뼈정렬의 정상적인 각도로 회복할 수 있는 기간과 변형된 정도 및 양상에 따라 적용프로그램이 다 르고 머리무게가 척추에 전달되는 부하 차이가 척추변 형을 유발하며 균형능력에 다른 영향을 줄 수 있기 때문 이다[22-23]. 그래서 목뼈정렬교정과 함께 교정된 목 뼈를 인정적으로 유지하며, 목 주변과 어깨근육의 유연 성을 높이고 근육밸런스 향상 효과가 나타날 것이다. 또 한 협응력 향상으로 낙상 위험요소 감소와 신체 활동 증 가 및 자세조절능력 증가로 일상생활에서 기능적인 능 력을 강화시키는데 중요한 중재 변인으로써 긍정적 결 과를 기대할 것으로 사료된다.

\section{결론}

본 연구에서 카이로프랙틱과 어깨 유연성 증가를 위 한 운동의 복합처치는 목뼈정렬이 변형된 대상자들의 목 뼈정렬을 효과적으로 교정하였으며, 정적 균형과 동적
균형을 판단할 수 있는 편향성이 유의하게 감소하는 결 과를 보였다. 카이로프랙틱과 어깨 유연성 증가 운동은 $\mathrm{VDT}$ 증후군 증상을 보이는 사람에 게 증상 완화 및 균형 능력 향상을 위한 기초자료로 활용될 것으로 생각된다. 따라서 향후 연구에서는, 목뼈변형의 정도를 구분하고 변형된 목뼈의 정도와 양상에 따라 균형능력에 미치는 영향을 연구할 필요성이 있다.

\section{Acknowledgments}

이 논문은 박일용의 박사학위 논문을 수정 보완 하 였습니다.

\section{Conflicts of Interest}

The authors declare no conflict of interest.

\section{References}

1. Korea Internet \& Security Agency. Summary report of the wireless internet access survey in 2012[Internet]. 2012; https://www.kisa.or.kr/eng/usefulreport/surveyReport_ View.jsp?cPage $=4 \& p \_N o=262 \& b \_N o=262 \& d$ $\mathrm{No}=50 \& S T=\& S V$. (Accessed May 12, 2014).

2. Mekhora K, Straker L Elimination of electrocardiograph noise in neck muscle electromyography. Ergonomics Australia. 1999; 13:15-21.

3. Lee S, Jeong BG, Lee GC, Lee GC, Bae SB. A study on health effects of VDT syndrome in hospital workers. J Nucl Med Technol. 2012; 16(2):87-98.

4. Doberczak, Tatiana M, Kandal, Stephen R, Wilets, Ilene. Neonatal opiate abstinence syndrome in term and preterm infants. J Pediatr. 1991; 118(6):933-7.

5. Sauter, Steven L, Schleifer, Lawrence M, Knutson, Sheri J. Work posture, workstation design, and musculoskeletal discomfort in a VDT data entry task. HUMAN FACTORS. 1991; 33(2):151-67.

6. Wade, Michael G, Jones, Graeme. The role of vision and spatial orientation in the maintenance of posture. Phys ther. 1997; 77(6):619-28.

7. Karatas M, Çetin N, Bayramoglu M, Dilek A. Trunk muscle 
strength in relation to balance and functional disability in unihemispheric stroke patients. Am J Phys Med Rehabil. 2004; 83(2):81-7.

8. Edmondston SJ, Wallumrød ME, MacLéid F, Kvamme LS, Joebges S, Brabham GC. Reliability of isometric muscle endurance tests in subjects with postural neck pain. J Manipulative Physiol Ther. 2008; 31(5):348-54.

9. Haughie, Laura J, Fiebert, Ira M. Roach, Kathryn E. Relationship of forward head posture and cervical backward bending to neck pain. J Man Manip Ther. 1995; 3(3):91-7.

10. Bronfort G, Haas M, Evans R, Bouter LM. Efficacy of spinal manipulation and mobilization for low back pain and neck pain: A systematic review and best evidence synthesis. Spine J. 2004; 4(3):335-56.

11. Ombergt, Ludwig. A system of orthopaedic medicine-EBook. Elsevier Health Sciences. 2013.

12. Lee WJ, Khil JH, Kim HC, Sung GS, Wo JE, Sun JS. Sports Chiropractic Library. Daekyung Books: Seoul. 2003.

13. Ogura T, Tashiro M, Masud M, Watanuki S, Shibuya K, Yamaguchi K, Yanai K. Cerebral Metabolic Changes in Men After Chiropractic Spinal Manipulation for Neck Pain. Altern Ther Health Med. 2011; 17(6):12-7.

14. Yoo WG, Yi CH, Kim MH. Effects of a proximity-sensing feedback chair on head, shoulder, and trunk postures when working at a visual display terminal. J Occup Rehabil. 2006; 6(4):631-7.

15. Shumway-Cook A, Woollacott MH. Motor Control: Translating Research into Clinical Practice 3th Edition. Lippincott, Williams \& Wilkins, Baltimore. 2007.

16. Han GS, Song IW. The Effect of Combined Exercise Program on Balance, Shoulder Gradient and Forward Head Posture in College Students. J Sports Sci Med. 2017; 26(3):1127-37.

17. Faul, Franz, et al. $G^{*}$ Power 3: A flexible statistical power analysis program for the social, behavioral, and biomedical sciences. Behav Res Methods. 2007; 39(2):175-91.

18. Jochumsen $\mathrm{OH}$. The curve of the cervical spine. ACA J Chiro. 1970; 4: 49-55.

19. Kim YH, Khil JH. Effects of Exercise Training and Chiropractic on Grip Strength and Cervical Muscle Strength of Subjects with Forward Head Posture and Turtle Neck. J Kor Phys Ther. 2017; 12(2):121-7.

20. Gross AR, Hoving JL, Haines TA, Goldsmith CH, Kay T, Aker P, Cervical Overview Group. A Cochrane review of manipulation and mobilization for mechanical neck disorders. Spine. 2004; 29(14):1541-8.

21. Kang JH, Park RY, Lee SJ, Kim JY, Yoon SR, Jung KI. The effect of the forward head posture on postural balance in long time computer based worker. Ann Rehabil Med. 2012; 36(1):98-104.

22. Freitas SM, Duarte M, Latash ML. Two kinematic synergies in voluntary whole-body movements during standing. J Neurophysiology. 2006; 95(2):636-45.

23. Cho YJ, Hwang R. Effect of Cervical and Thoracic Stretching and Strengthening Exercise Program on Forward Head Posture. JKCA. 2011; 11(10):293-300.

24. Seidi F, Rajabi R, Ebrahimi I, Alizadeh MH, Minoonejad $\mathrm{H}$. The efficiency of corrective exercise interventions on thoracic hyper-kyphosis angle. J Back Musculoskelet Rehabil. 2014; 27(1):7-16.

25. Park JW, Kim SJ, Jeong SH. Juvenile, adolescent idiopathic scoliosis treated with chuna manipulation and foot orthosis treatment: four clinical cases report. J Korean Med Rehabi. 2013; 23(1):65-75.

26. Oh DG, Sung SC, Lee MG. Effects of combined treatment of chiropractic and PNF exercise on musculoskeletal function in forward head posture patients. Korean J Sport Sci. 2016; 27:258-71. 